\title{
Theoretical and practical aspects of health physical education in the Czech Republic
}

\author{
Iva Dostálová, Martin Sigmund, Jana Kvintová
}

\begin{abstract}
The article deals with the issue of health physical education and its theoretical definition. It provides an overview of the possibilities of further education in this area and informs of the state of health physical education in elementary and secondary schools as well as in universities.

Health physical education is based on the Framework Educational Programme and is classified in the field of Physical Education. The contents of health physical education are primarily compensatory exercises. Health physical education is focused on consolidating and improving the health of individuals with a physical impairment, which is based on an assessment of general practitioners for children and adolescents. Health physical education requires qualified educators; however, there is still a lack of them. Similarly, there is an insufficient number of health physical education departments despite the fact that there are more and more individuals suffering from a health impairment, especially with a weakened musculoskeletal system. Further training of qualified educators and thus qualified teaching of health physical education is necessary for strengthening and correcting the health condition of our trainees.
\end{abstract}

Key words: Health impairment, correction, physical education, compensatory exercise, teacher training. 


\section{Introduction}

The positive effect of physical activity on human health and harmonious development of an individual has been recognized since ancient times. As early as the third millennium BC, the Chinese used respiratory gymnastics as therapy. In ancient Indian medicine, they were aware of the importance that exercise brings to health. An ancient exercise system of yoga, particularly Hatha Yoga, is used even today. Greek physical gymnastics were individually targeted and supplemented with massages and dietary habits. The purposes of life for the Greeks were beauty, body fitness and nobility of mind called "Kalokagathia" (Škvára and Srdečný, 1973).

Much later, similar ideas were advocated by J. A. Comenius, for whom the ideal man was a healthy, fit, moral and helpful person. The idea of harmonious development of man was also embraced by the founders of the Sokol movement Tyrš and Fügner with a famous slogan, "In a healthy body there is a healthy spirit."

Therapeutic elements of health exercise formed the basis of the first orthopaedic institute in our country founded in 1839 by Dr. Hirsch. Remedial gymnastics was based on a Swedish concept of the Ling's physical education system built on physiological and anatomical knowledge. Three years later in Prague, the author of "Outline of Healing Physical Education," Jan Spott, established the first medical institute. During the following years other physical education handbooks emerged and therapeutic physical education was introduced. The need to care for the weak was completed in 1913 by the foundation of the Jedlička Institute in Prague, which was the "Institute for Treatment and Education of Cripples" (Škvára and Srdečný, 1973). Similar rehabilitation and orthopaedic institutes were also established in other cities.

In 1950 the Ministry of Education introduced "special physical education," which was optional on all stages of the educational system. Special physical education was primarily taken by students with orthopaedic problems. It took quite a long time to enforce voluntary forms of physical education for physically impaired individuals. In 1982 health physical education emerged as a voluntary form of physical education and the name was gradually being introduced in all types of schools.

Currently, health physical education is being systematically and intensively developed and is intended for individuals with health problems and aimed at health-oriented activities that have preventive as well as therapeutic importance and influence health condition of an individual in terms of optimization, stabilization or mitigation of progression. 


\section{Objective}

The objective of the article is to provide an overview of the issue of health physical education and its theoretical bases including the description of health physical education in elementary and secondary schools as well as in universities.

\section{Physical education}

Physical education involves a wide range of organized and non-organized physical activities and represents an individual subject within the educational system.

\section{"School" Physical Education}

Physical education is a mandatory subject in the Czech Republic usually consisting of two lessons a week. (In sport schools the number of lessons a week is usually increased by two lessons.) Due to changing living conditions, the number of physical education lessons appears insufficient to maintain basic health fitness of the organism. Students should be comprehensively encouraged to care for the physical, mental and social aspects of their personalities. They should strengthen their attitudes towards physical activities, be able to determine an appropriate daily routine with a sufficient amount of suitably selected physical activities and also should be able to relax and regenerate their stamina with respect to the ever-increasing pace of life.

Physical education must be taken by students classified in health groups I and II. They may also take any kind of sport at a top or recreational level in full extent in line with ontogenetic trends and gender-related peculiarities of the organism. Physical education programs are led by a qualified educator.

\section{Health Physical Education}

Health physical education is not offered as a subject in all types of schools. Its integration into the educational process currently depends on the cooperation and initiative of the headmaster of the school and PE teachers, pressure exerted by the parents and collaboration with physicians. If health physical education is included among the subjects taught, it is usually one lesson a week. Due to the fact that even in PE lessons there is not enough space for proper posture correction, practising appropriate movement habits etc., similarly, the extent of health physical education is not sufficient to compensate for particular types of impairment.

Health physical education should be taken by student classified in health group III and is open to healthy students who wish to deepen their knowledge and practical 
skills and use it as a means of prevention. At the same time, health impaired individuals can attend "school" physical education, in which the respective type of impairment is taken into consideration. Any sports activities should be of a recreation nature and should under no circumstances worsen their health impairment.

Health physical education is led by an educator with appropriate qualification in order to lead the trainees in a professional way and consult their health condition with a physician.

\section{Therapeutic Physical Education}

Therapeutic physical education is led by an experienced physiotherapist in close collaboration with a physician. It is exclusively intended for sick individuals classified in health group IV who should not take "school" physical education.

\section{Definition of health physical education}

Health physical education is a deliberately led didactic process, whose task is to provide physical competence to people with a health impairment. This particularly includes adoption of selected health-oriented physical skills (Hošková and Matoušová, 2007).

Hálková et al. (2001, p. 5) states that, "Health physical education is a form of physical education intended for individuals with a health impairment, i. e. individuals in health group III according to medical classification." A similar definition of health physical education comes from Kopecký (2010, p. 7), "Health physical education is a specific form of compulsory school physical education intended for children classified in health group III, or a form for individuals with temporary health impairment who cannot perform some activities in school physical education for health reasons."

A different definition was produced by Strnad (2005) who states that health physical education is a form of physical education process within our educational system. It is aimed at strengthening and improving the health of individuals with health impairment.

According to Strnad, Hendl and Kyralová (2007), the subject of health physical education is intended for students in health group III and fulfils health prevention as well as a therapeutic function.

A comprehensive view of health physical education underpinned by available literature sources, both past and contemporary, can be summarized in the following characteristics of health physical education:

"Health physical education is a specific form of physical education intended for individuals with health impairments and is aimed at health-oriented activities that have preventive as well as therapeutic results leading to strengthened and improved 
health. Health impairment represents deviations from healthy physical development and can be of a temporary or permanent nature."

Health physical education is based on the Framework Educational Programme and is classified in the field of Physical Education.

From above it is obvious that health physical education is primarily intended for weakened individuals classified in health group III. The classification of individuals into health groups is based on Directive No. 3/1981 of the Ministry of Health of the Czech Republic on care and health during physical education and sport. The evaluation of health condition in relation to physical education is performed by general practitioners and sports physicians for children and adolescents. An overview of health groups is specified in Table 1.

Tab. 1: Health groups related to physical education

\begin{tabular}{|c|l|l|}
\hline $\begin{array}{c}\text { Health } \\
\text { group }\end{array}$ & Health condition & Physical education \\
\hline I. & $\begin{array}{l}\text { Healthy individuals, appropriately developed, with a high } \\
\text { degree of fitness }\end{array}$ & $\begin{array}{l}\text { School physical education and sport without limitation } \\
\text { (except age and gender-based peculiarities) }\end{array}$ \\
\hline II. & Healthy individuals, less trained & $\begin{array}{l}\text { School physical education and sport without limitation } \\
\text { (except age and gender-based peculiarities) }\end{array}$ \\
\hline III. & $\begin{array}{l}\text { Impaired individuals with permanent or temporary de- } \\
\text { viations from physical development }\end{array}$ & $\begin{array}{l}\text { School physical education with exemptions according to } \\
\text { type of impairment, health physical education, sport } \\
\text { according to type of impairment }\end{array}$ \\
\hline IV. & Sick individuals & $\begin{array}{l}\text { Therapeutic physical education, exemption from school } \\
\text { physical education }\end{array}$ \\
\hline
\end{tabular}

There are a total of four health groups identified with Roman numerals. The first and the second groups include healthy individuals, who vary slightly in physical fitness between the two groups. The third group includes health impaired individuals, who have permanent or temporary deviations from physical development, physique or health condition. Health impairment does not allow them to take part in physical education or certain physical activities and exercises in full extent; these could be due to the nature of the impairment contraindicative. This group temporarily includes students after injuries for a period required for recovery; these students are temporarily exempt from mandatory physical education due to the nature of the injury by their physicians. The fourth group includes sick individuals.

The aim of health physical education is, in addition to all-round and harmonious development of an individual (as in the case of physical education), to influence the health condition of an individual in terms of optimization, stabilization or mitigation of progression. In case of functional disorder, if the defect is not fixed, or the impairment has not become chronic, we try to compensate the impairment. However, if the defect 
becomes fixed, we try to stabilize the health condition, or at least prevent significant deterioration of the impairment. At the same time we strive to increase or maintain functional fitness of the organism.

In the area of education our aim is to deepen the knowledge of own impairment and the possible ways of remedy. Due to the fact that we also face temporary impairment, particularly in connection with the musculoskeletal system, i.e. sprains, fractures, etc. (exemption from school physical education for a period of several weeks and assignment to health physical education), it is important to educate the individuals also in terms of such short-term conditions. We try to deepen and strengthen basic motor skills and habits in an individual with regard to the type and degree of impairment (selection and choice of exercises, volume and intensity of exercise, self-correction during the day, ergonomic adjustments, contraindicative activities, etc.). The educational mission is to strengthen the relationship with physical activity, to be able to create adequate daily routine and appropriately care for the body not only physically but also mentally.

The content of health physical education should correspond with all the objectives defined - general, health, and educational. Likewise, the content should correspond with the type of impairment and respect the different age groups. The choice of aids in health physical education is based on physical education. We try to create a positive effect on health through physical exercise and physical activity

\section{Compensatory exercise in health physical education}

Compensatory exercise focuses on a certain correction, which may involve modification of muscle imbalance, incorrect position of the articular segment, poor posture, and also poor respiratory function, etc. Therefore, various publications identify this type of exercise as corrective exercise, straightening exercise (derived from standing straight) or compensatory exercise, which is probably a term most accurately capturing the essence.

Dobešová (2011) states that compensatory exercise is designed for practicing optimum posture in various positions and during movement. Čermák, Chválová, Botlíková and Dvořáková (2000) identify balancing or compensatory exercise as activities which can be targeted as the components of the locomotive system to improve their functional parameters and thus balance the unfavourable ratio between the functional fitness of the locomotive system and its load resistance on the one hand and functional demands that are placed on it on the other. According to Bursová (2005), compensatory exercise is a variable set of simple exercises in exercise positions, which can be effectively modified using various equipment and aids. Hošková and Matoušová (2007) point out that due to the nature of compensatory exercise, it should be mainly included in the preparatory "school" physical education because it can very effectively influence the condition of the locomotive system - compensate muscle imbalance and prevent vertebrogenic difficulties. 
Compensatory exercise comes from the word compensation, which means to reach mutual balance (from the Latin "com-pensó", i. e. balance). Compensatory or balancing exercise is a set of specific exercises that have a positive effect on individual components of the musculoskeletal system (muscles, ligaments, tendons, joints and bones) and also influence other organ systems and affect overall physical and mental development of an individual.

According to a specific focus and predominant physiological effect compensatory exercise is divided into the following in the narrowest sense:

Releasing exercise,

Stretching exercise,

Fitness exercise.

Physical exercise is practically performed in basic exercise positions (lie, support, front support, kneel, sit and stand), mastering of which is essential for proper compensatory exercise. If the initial exercise position is incorrect, compensatory exercise might not fulfil its compensatory function. On the contrary, it can be contraindicative.

For an individual to be able to properly take an exercise position, one must be capable of perceiving their own body, individual body segments, their mutual position, their position with respect to the mat, and their mutual cooperation. Similarly, one should be able to, throughout the whole movement, maintain a mutual position of various locomotive segments and fix them in the correct position. Therefore, the basic division of compensatory exercise is further extended with the following:

Self-awareness exercise,

Stabilising exercise.

Another logical sequence is represented by the respiratory system. It is obvious that for proper functioning of the muscles a sufficient amount of nutrients and oxygen is required. Breathing as such has a strong modulating function and, in a reflexive way, helps to decrease muscle tension. If we want to perform individual exercise shape, we need to learn proper breathing habits and breathing techniques, which is closely related with performing the exercises. Further differentiate compensation exercises. The following compensatory exercise is identified:

Respiratory exercise,

Relaxing exercise.

Respiratory exercises can also be used as separate exercises in case of respiratory impairment. Breathing is related with relaxation of the organism. Relaxing exercises release muscles and regulate mental tension. They are a means for inducing a harmonious balance in the body. 
Further classification of physical exercise can be done based on various perspectives:

Balanced exercise,

Coordinating exercise,

Exercise to develop endurance,

Exercise to develop strength,

Exercise to develop speed,

Drill exercise,

Fitness exercise,

Health exercise,

Rehabilitation exercise etc.

In addition to physical exercise, mainly compensatory exercise, health physical education uses various kinds of physical activity, which is more of a recreational nature. These primarily include basic physical locomotion - waking and its various modifications ranging from walking, jogging over to various forms of Nordic walking. For younger age categories, they include diverse forms of climbing and climbing over, whereas older individuals enjoy appropriate physical activity such as swimming and a variety of physical activities in water. Currently, a large number of different exercise trends emerge and interconnect in different ways. It is always necessary to keep in mind the quality of the exercise or physical activity performed and one's own health impairment.

With respect to the educational objectives, health physical education will include a simple functional diagnostics so that impaired individuals have feedback and are able to capture the initial condition as well as any changes achieved through exercise or daily correction (for example, holding the respective body segment) and ergonomic modifications.

In health physical education we can use the same aids and equipment as in physical education. The basic aids include a soft mat, exercise mat, fitness mat, foam mat, etc. The basic equipment includes a gym carpet, vaulting box, bench, wall bars and climbing ladders. Further usable tools are mainly exercise bars, different kinds of expanders - therabands, aerobic bands, eight-shaped expanders and dumbbells or minor (low weight) weights designed for the limbs. Specifically designed aids include large balls and ovals - gymballs, fitballs, eggballs, and small balls - overballs, foam balls, antistressballs, etc. Acupressure tools used for exercise include acupressure rollers, balls and pads and massage tripods, massage octopuses and massage slippers. We can also use balance discs, ovals and mats. Newer exercise trends are, for example, bosu and roller pilates, circle pilates. Other aids include foam rollers, fitness flexi-bar, various types of sitting wedges, finger exercisers, exercise with powerball, etc. 


\section{Forms of organization in health physical education}

Health physical education is usually organized in regular exercise units. In terms of duration, the following forms of organization are distinguished:

Exercise unit $(45,60$ or 90 minutes),

Half-day event,

Whole-day event,

Several days' event (weekend, long weekend, week).

In terms of institutions and facilities, the following can organize health physical education:

Elementary schools,

Secondary schools,

Universities,

Sports organizations,

Community organizations,

Individually in a home environment.

Within the educational system, health physical education is a non-compulsory subject and it is up to schools if they decide open it and make it available for students. Health physical education can be organized in schools as a voluntary afternoon form of exercise not only for pupils and students, but also for the wide public interested in strengthening their health. Among sports and community organizations, it is primarily Sokol with a strong tradition and the Czech Association Sport for All which established a Health Physical Exercise Board and issued a directive governing education in this area. Currently, health physical education can be offered also by private organizations and individuals with the required accreditation. Health physical education can also be applied directly in a home environment and its components should be an inseparable part of "school" physical education and quality sports training.

\section{Types of health impairment}

Within the system of health physical education, health impairment is classified into three basic groups.

\section{Impairment of the musculoskeletal system}

Disorders of muscle balance in the locomotive segments, disorders of neuromuscular coordination, hypermobility, hypomobility, poor posture; 
Disorders and defects of the spine in the sagittal position - increased lumbar lordosis, increased thoracic kyphosis (round back) kypholordotic posture, flat back;

Disorders and defects in the lateral position of the spine - scoliotic posture and scoliosis; Vertebrogenic disorders - post-traumatic conditions, post-operative conditions, chronic conditions;

Weakened lower limbs - weakened hip and knee joints, flat feet, foot defects and deformities, paresis, post-traumatic conditions, post-operative conditions, chronic conditions;

Weakened upper limbs - weakened shoulder and elbow joints, joint deformities, paresis, post-traumatic conditions, post-operative conditions, chronic conditions; Osteoporosis, arthrosis.

\section{Impairment of internal organs}

Impairment of the respiratory system - asthma, bronchitis, pneumonia, laryngitis, sinusitis, allergies and others;

Impairment of the cardiovascular system - hypertension, hypotension, cardiac arrhythmia, ischemic heart disease (myocardial infarction, angina pectoris), congenital heart defects, varicose veins, atherosclerosis, etc.;

Impairment of the endocrine system - diabetes mellitus, thyroid disorders, etc.;

Metabolic disorders - obesity;

Gynaecological impairment - menstrual cycle disorders, menopause, sterility, gravidity, incontinence, etc.;

Gastrointestinal impairment - stomach ulcers, hernia, etc.

\section{Impairment of the sensory and neural functions}

Impairment of sight - shortsightedness, farsightedness, night blindness, colour blindness, strabismus, glaucoma, cataract, partial sight, etc.;

Impairment of hearing and the statokinetic system - hearing loss, balance disorder, disturbance in orientation, dizziness, etc.;

Neuropsychical disease - neurosis, psychosis, epilepsy, cerebral palsy, ADHD, anorexia nervosa and bulimia nervosa, Alzheimer's disease, Parkinson's disease, etc.

Each type of health impairment of an individual should be considered from more viewpoints, which will define the impairment. It must be considered whether the impairment is:

Congenital or acquired,

Of a functional or structural nature,

Temporary (post-traumatic condition) or permanent (chronic changes),

Acquired in childhood or adulthood. 
The content of a health physical education shall be arranged especially according to the type of impairment and also in relation to age peculiarities and intellectual maturity of the individuals. Accordingly, appropriate means and aids targeted on improving the health condition of the individuals should be selected.

\section{Educational system in health physical education}

In schools, health physical education should be led by teachers qualified in health physical education, in sports institutions by grade III - I instructors qualified in health physical education. A precondition for teaching health physical education in elementary and secondary schools is a good cooperation of teachers and physicians.

The Health Physical Education Board is a part of the Czech Association of Sport for All (ČASPV). Teaching of health physical education is based on a ČASPV Directive No. M - 8/1995/10-4 (effective as of 1 March 2010). To get grade III (basic) qualification in health physical education, an instructor must successfully complete an educational programme of 50 lessons (minimum age 18). For extended qualification - grade II, an instructor must complete 50 lessons (minimum age 18). An instructor of standardized grade I qualification must complete at least $50+10$ lessons (minimum age 21). Standardized (accredited) grade I qualification has a minimum extent of 150 lessons and comply with the requirements of the Trade Act. The period of validity of the qualification, particularly in lower grades, might be time limited.

Based on achieved degree in physical education, grade III qualification in health physical education might be awarded to the following graduates: secondary nursing schools, field of study: Rehabilitation; higher vocational schools, specialization: Rehabilitation; Faculty of Physical Education and Sport, Charles University, field of study: Physiotherapy, Bachelor degree; and Faculty of Medicine, field of study: Rehabilitation, Bachelor degree.

In order to get grade III instructor qualification, graduates from the Faculty of Physical Education and Sport, Charles University, or any faculty of education, field of study: Physical Exercise, or any faculty of education, field of study: Teaching Physical Education (Bachelor as well as Master) are required to complete the subject of Health Physical Education in the respective study year by taking an exam. Detailed requirements for grade II and I instructors are detailed in the Directive.

Instructor qualifications in health physical education can also be awarded by other departments with the required accreditation. The subject of Health Physical Education was modified for the graduates from faculties of physical education and sport, especially after transition to a two-level study model - Bachelor and follow-up Master degree program. This modification included a decrease in the number of lessons, completion of the course only by a term exam in the Bachelor course, etc. This applies not only to single-subject and double-subject teaching studies of physical education but also to 
other physical education and sport fields. The above implies that not every graduate from a physical education teaching course is qualified to lead health physical education, contrary to the original comprehensive five-year course.

\section{Health physical education in school educational programmes}

Health physical education is based on the Framework Educational Programme and is classified in the area of People and Health. In terms of content, health physical education is classified in the field of Physical Education.

In his conclusions on the state of the subject of health physical education in our elementary and secondary schools, Strnad (2007) points out that the Framework Educational Programmes do not specify mandatory content, extent and conditions of education of students with health impairment and disability in the subject of health physical education. His research shows that $51 \%$ of teachers have no experience with health physical education and, therefore, it cannot be anticipated that compensatory exercise will be included in the preparatory parts of physical education lessons. At the same time, as mentioned above, the proportion of children and young people with disorders of the musculoskeletal system increases. Similarly, Kopecký (2010) states that $50-60 \%$ of children have poor posture, and therefore, should take special compensatory exercise. We also came to similar conclusions while monitoring the incidence of muscle imbalances in various population groups (Dostálová, 2002; 2005; 2007; Dostálová, Přidalová and Remsová, 2004; Dostálová, Riegerová and Přidalová, 2007).

\section{Current state of health physical education in schools}

The latest comprehensive survey of the state of health physical education in elementary and secondary schools in the Czech Republic was performed by Strnad (2005). The obtained results reflect the long-term plight in this area at all levels and in all aspects of health physical education, whether it be elementary or secondary schools or universities; teachers, head-teachers, physicians or ministries.

Within the following grant project - Systematic monitoring of health impaired pupils and students in health physical education and proposals for improvements in the education system in the Czech Republic, administered by the Ministry of Education, Youth and Sports, a total of 1,330 schools and 56 general practitioners for children and youth were addressed (Strnad and Hendl, 2007; Strnad, Hendl and Kyralová, 2007). 
The results are summarized by Strnad (2007) in several areas. The first is insufficient teacher qualification. The results show that $51 \%$ of PE teachers lack experience in health physical education. Moreover, in spite of all their effort, it is impossible to allocate sufficient time for corrections in impaired individuals in PE lessons. After reaching a university degree, $75 \%$ of addressed PE teachers did not pass any other educational course aimed at deepening their knowledge in health physical education.

Currently, health physical education is taught by $218(16 \%)$ of teachers out of the total number of addressed PE teachers (Strnad and Hendl, 2007). The responses of the teachers further indicate that there was a decrease in health physical education lessons in schools, mostly due to financial and timetable reasons, not because of insufficient teacher qualification. The decreased number of health physical education lessons is also influenced by the introduction other optional subjects. The reduced number of health physical education lessons is an issue not only in elementary and secondary schools but also in universities, which should, on the contrary, try to increase teacher qualifications in this area.

On the one hand there is a reduction in health physical education at all school levels, on the other hand there are more individuals with various types of impairment in lower age categories. The following table (Table 2) presents estimated incidence of different types of health impairment as viewed by physicians in secondary and elementary school students and reasons leading to exemption from school physical education as viewed by teachers (modified according to Strnad and Hendl, 2007 and Strnad, Hendl and Kyralová, 2007).

Tab. 2: Incidence of health impairment in elementary and secondary school students

\begin{tabular}{|l|c|c|}
\hline \multicolumn{2}{|c|}{ Representation of different types of impairment } \\
\hline Impairment & $\begin{array}{c}\text { Physicians } \\
\text { Estimated incidence (\%) }\end{array}$ & $\begin{array}{c}\text { Teachers } \\
\text { Reasons for exemption from PE (\%) }\end{array}$ \\
\hline Locomotive system impairment & 33 & 51 \\
\hline Respiratory system impairment & 14 & 25 \\
\hline Cardiovascular system impairment & 3 & 13 \\
\hline Neuropsychical impairment & 2 & 7 \\
\hline Metabolic impairment & 3 & 5 \\
\hline Sensory impairment & 5 & 2 \\
\hline Gynaecological impairment & - & 3 \\
\hline Allergy & - & 22 \\
\hline Other types of impairment & - & 18 \\
\hline Injuries & - & 18 \\
\hline
\end{tabular}


It is obvious that even cooperation with physicians is not ideal. Both teachers and physicians have serious comments on the classification of students into health groups and on insufficient awareness of physicians in terms of what an individual can or cannot do in physical education, the length of exemption from school physical education in case of post-traumatic conditions, etc. These facts are also confirmed by students of combined study of Physical Education, Applied Physical Education and Teaching for Primary Schools who are on teaching practice and showed deeper interest in the health condition of the students.

\section{Conclusions}

Health physical education has a unique place in the educational system. It is necessary to ensure qualified teaching of physical education and health physical education at all school levels and education of qualified teachers. Their knowledge and skills must be further deepened in order to ensure to support the health of students in terms of educational and health-related aspects.

\section{Acknowledgements}

This article is a part of the project "Preparation for physical education of persons with disability" CZ.1.07/2.2.00/15.0336 supported by ESF and the budget of the Czech Republic.

\section{References}

Bursová, M. (2005). Kompenzační cvičení. Praha: Grada Publishing.

Čermák, J.,Chválová, O., Botlíková, V. \& Dvořáková, H. (2000). Záda už mě nebolí. Praha: Jan Vašut. Česká asociace Sportu pro všechny. (2010) Směrnice ČASPV. M - 8/1995/10-4.

Dobešová, P. (2011). Didaktika TV 1. Ostrava: Ostravská univerzita.

Dostálová, I. (2002). Rozbor svalových funkcí u dětí mladšího školního věku. In Riegerová, J. (Ed.) Sborník V. celostátní konference v oboru funkční antropologie a zdravotní tělesné výchovy. Olomouc: Univerzita Palackého, pp. 32-33.

Dostálová, I. (2005). Stav svalového aparátu dívek mladšího školního věku. In Nosek, M. (Ed.) Sborník referátů z vědeckého semináře s mezinárodní účastí Pohybové aktivity a zdraví člověka. Ústí nad Labem: Univerzita Jana Evangelisty Purkyně, pp. 24-28.

Dostálová, I. (2007). Somatická charakteristika a analýza svalových funkcí dívek staršího školního věku se specificky zaměřenou pohybovou aktivitou. Disertační práce. Olomouc: Univerzita Palackého, Fakulta tělesné kultury,

Dostálová, I., Přidalová, M. \& Remsová, J. (2004). Stav svalového aparátu žáků 1. tříd základní školy. Česká antropologie. No. 54, pp. 62-63. 
Dostálová, I., Riegerová, J. \& M. Přidalová. (2007). Kvalita hybných funkcí svalového systému dívek staršího školního věku. Česká antropologie. No. 57, pp. 31-34.

Hálková, J. et al. (2001). Zdravotní tělesná výchova. Praha: Česká asociace Sport pro všechny.

Hošková, B. \& M. (2007). Matoušová. Kapitoly z didaktiky zdravotní tělesné výchovy. Praha: Karolinum.

Kopecký, M. (2010) Zdravotní tělesná výchova. Olomouc: Univerzita Palackého, Fakulta tělesné kultury.

Strnad, P. (2005). Současný stav vyučovacího předmětu zdravotní tělesná výchova na základních a středních školách. Praha: Univerzita Karlova, Fakulta tělesné výchovy a sportu.

Strnad, P. (2007). Závěry výzkumné zprávy o stavu vyučovacího předmětu zdravotní tělesná výchova na našich základních a středních školách a z nich vyplývající doporučení. Tělesná výchova a sport mládeže. No. 73 (7), pp 19-24.

Strnad, P. \& Hendl, J. (2007). Neutěšený stav zdravotní tělesné výchovy na základních a středních školách v České republice. Tělesná výchova a sport mládeže. No. 73 (5), pp. 9-18.

Strnad, P., Hendl, J. \& KYRALOVÁ, M. (2007). Současný stav zdravotní tělesné výchovy na základních a středních školách z pohledu praktických lékařů pro děti a dorost. Tělesná výchova a sport mládeže. No. 73 (6), pp. 11-19.

Škvára, F. \& Srdečný, V. (1973). Teorie vyučování zvláštní tělesné výchově. Praha: SPN.

\section{Contact:}

RNDr. Iva Dostálová, Ph.D., Martin Sigmund

Department of Adapted Physical Activity

Faculty of Physical Culture

Palacký University, Olomouc

tř. Míru 115

77111 Olomouc, Czech Republic

E-mail: iva.dostalova@upol.cz

PhDr. Jana Kvintová, Ph.D.

Department of Psychology

Faculty of Education

Palacký University, Olomouc

Žižkovo nám. 5

77140 Olomouc, Czech Republic

E-mail: jana.kvintova@upol.cz 